\title{
Article
}

\section{Diagnosis of Helicobacter pylori Infection in a Routine Testing Workflow: Effect of Bacterial Load and Virulence Factors}

\author{
Nabil Gastli ${ }^{1}$, Margaux Allain ${ }^{1}$, Dominique Lamarque ${ }^{2}$, Vered Abitbol ${ }^{3}$, Annick Billoët ${ }^{1}$, Gislène Collobert ${ }^{1}$, \\ Romain Coriat $^{3}{ }^{-}$, Benoit Terris ${ }^{4}$, Nicolas Kalach ${ }^{5}$ and Josette Raymond ${ }^{1,6,7, * \mathbb{C}}$
}

1 Service de Bactériologie, AP-HP Centre-Université de Paris, Hôpital Cochin, 75014 Paris, France; nabil.gastli@aphp.fr (N.G.); marguax.allain@gmail.com (M.A.); annick.billoet@aphp.fr (A.B.); gislene.collobert@aphp.fr (G.C.)

2 Gastroentérologie, Hôpital Ambroise Paré, AP-HP, Université Versailles-Saint Quentin-en-Yvelines, 92100 Boulogne, France; dominique.lamarque@aphp.fr

3 Gastroentérologie, AP-HP Centre-Université de Paris, Hôpital Cochin, 75014 Paris, France; vered.abitbol@aphp.fr (V.A.); romain.coriat@aphp.fr (R.C.)

4 Anatomopathologie, AP-HP Centre-Université de Paris, Hôpital Cochin, 75014 Paris, France; benoit.terris@aphp.fr

5 Clinique pédiatrique Saint Antoine, Hôpital Saint Vincent de Paul, Groupement des Hôpitaux de l'Institut Catholique de Lille (GHICL), 59020 Lille, France; kalach.nicolas@ghicl.net

6 Service de Bactériologie, AP-HP Université Paris-Saclay, Hôpital Bicêtre, 94270 Le Kremlin-Bicêtre, France

7 Hôpital de Bicêtre, 78 Rue du Général Leclerc, 94270 Le Kremlin-Bicêtre, France

* Correspondence: josette.raymond@aphp.fr

\section{check for} updates

Citation: Gastli, N.; Allain, M.; Lamarque, D.; Abitbol, V.; Billoët, A.; Collobert, G.; Coriat, R.; Terris, B.; Kalach, N.; Raymond, J. Diagnosis of Helicobacter pylori Infection in a

Routine Testing Workflow: Effect of Bacterial Load and Virulence Factors. J. Clin. Med. 2021, 10, 2755. https:// doi.org/10.3390/jcm10132755

Academic Editors: Maxime Pichon and Christophe Burucoa

Received: 24 May 2021

Accepted: 18 June 2021

Published: 23 June 2021

Publisher's Note: MDPI stays neutral with regard to jurisdictional claims in published maps and institutional affiliations.

Copyright: (c) 2021 by the authors. Licensee MDPI, Basel, Switzerland. This article is an open access article distributed under the terms and conditions of the Creative Commons Attribution (CC BY) license (https:// creativecommons.org/licenses/by/ $4.0 /)$.

\begin{abstract}
Reliable diagnostic methods are mandatory for effective management of Helicobacter pylori infection. Histology and culture are the most common invasive methods in current practice, even if molecular methods are gaining in importance. The performance of these conventional methods varies significantly. We conducted a retrospective study of 1540 adults and 504 children with gastric biopsies taken during endoscopy to assess the impact of bacterial load and the cag $A$ virulence factor on the performance of $H$. pylori infection testing. The association between virulence and histology findings was also investigated. With $23 \mathrm{~S}$ rRNA qPCR confirmed by glmM amplification as the gold standard, culture and histology had lower sensitivity, $74.4 \%$ and $73.3 \%$, respectively. However, their sensitivity was enhanced (>90\%) in biopsies with high bacterial load (qPCR Ct $<30$ ). Positive $\operatorname{cag} A$ status of the strain was associated with high bacterial load $(94.9 \%)$, thus resulting in more frequent positive culture (94.3\%) and $H$. pylori histology detection (91.7\%) and more severe lesions on histology $(p<0.001)$. Conversely, the $\operatorname{cag} A$ status of the strains was negative in $110 / 119(92.4 \%)$ of biopsies with low bacterial load (qPCR Ct < 30), 82/90 (91.1\%) with negative H. pylori histology detection and $119 / 131(90 \%)$ with negative culture findings $(p<0.001)$. This study highlights the low sensitivity of conventional culture and histology that may lead to false negative diagnosis if used alone. $H$. pylori quantification associated with $\operatorname{cag} A$ genotyping in routine workflow are essential for a sensitive and reliable diagnosis, to identify patients at high risk and to manage eradication therapies.
\end{abstract}

Keywords: Helicobacter pylori; cagA gene; PCR; diagnosis; histology; culture

\section{Introduction}

Helicobacter pylori infection is related to a wide spectrum of diseases including uncomplicated or complicated ulcer diseases, mucosa-associated lymphoid tissue lymphoma, atrophic gastritis and gastric cancer. The correct management of these severe conditions requires constant collaboration between gastroenterologists, pathologists and biologists.

H. pylori infection can be diagnosed by the non-invasive techniques serology, 13C urea breath test and stool antigen test, even if the strategy "test and treat" is no longer recommended. The other approach requires gastric biopsy collection during endoscopy and then analysis by urease tests, histopathology, culture and/or molecular detection by 
PCR [1]. Histology allows for detecting H. pylori and tissue damage and is one of the most commonly used methods. Indeed, the Maastricht consensus states that most cases can be diagnosed by only histochemical staining of biopsies [2].

H. pylori culture is essential for in vitro susceptibility testing but requires welltrained laboratory staff. Molecular methods allow for high sensitivity and detection of both $H$. pylori DNA and specific point mutations associated with clarithromycin resistance. This promotes easier administration of a tailor-made treatment as recommended [2]. This approach also offers the possibility of quantifying bacterial load and screening virulence factors.

In 2011, Espinoza et al. recommended the use of the glmM gene for detecting $H$. pylori [3]. Indeed, the housekeeping gene $g \operatorname{lm} M$ is essential for bacterial growth and cell-wall synthesis and is therefore specific to $H$. pylori [4]. Hence, we systematically used H. pylori-specific glmM PCR to confirm qPCR results.

Among multiple virulence factors identified in H. pylori, two main factors associated with gastric epithelial cell pathogenicity have been extensively studied: cytotoxinassociated gene $\mathrm{A}(\mathrm{Cag} \mathrm{A})$ protein, coded by the cag $A$ gene that is part of the cag pathogenicity island (cag-PAI), and the pore-forming cytotoxin called vacuolating cytotoxin (VacA) [5]. CagA is directly injected into epithelial cells via a type IV secretion system and undergoes tyrosine phosphorylation within repeated sequences of five amino acids (glutamic acid, proline, isoleucine, tyrosine, alanine), called EPIYA motifs. The phosphorylated form is able to deregulate normal cellular signaling. The cag $A$ gene is grouped into two different allele types: Western alleles that encode one or multiple EPIYA-C motifs and East Asian alleles that encode one EPIYA-D motif [6].

The severity of gastric lesions was suggested to be associated with cagA status and vacA polymorphism [7-9]. Moreover, quantitative molecular methods in earlier observations showed an association between $\operatorname{cag} A$ status and bacterial density, thus suggesting a potential impact of virulence factors on performance of the diagnostic method [10].

The aim of our study was to assess, in a large French cohort of adults and children, the genotypes of $\operatorname{cag} A$ and $v a c A$ and investigate their association with histology findings and their effect on the performance of conventional methods for bacterial detection.

\section{Material and Methods}

\subsection{Patients, Endoscopy and Gastric Biopsy Sampling}

From January 2017 to April 2019, 2044 patients (1540 adults and 504 children), all presenting gastrointestinal disorders, underwent upper gastrointestinal endoscopy, with gastric biopsy sampling and testing for $H$. pylori infection performed in the bacteriology laboratory of Cochin Hospital (Paris, France). Adults attended the gastroenterology units of Cochin Hospital or Ambroise Paré Hospital (Boulogne, France), whereas children attended the Saint Vincent de Paul Hospital (Lille, France). Biopsies were taken from both the gastric antrum $(n=4)$ and corpus $(n=4)$. Patients who had received antibiotics during the previous 4 weeks or proton pump inhibitors (PPIs) during the previous 2 weeks were excluded. All samples were submitted for routine diagnostics. Patients were investigated in a hospital setting, according to good clinical practices.

Written informed consent for the endoscopic and diagnostic procedures was obtained from patients or their parents/legal guardians and kept in their medical records. The study was carried out in care structures, which have a CNIL correspondent who ensures data compliance. No extra biopsy sampling or additional endoscopies were required, and all samples were anonymized. This is a retrospective study therefore non-interventional study. Furthermore, in France no declaration to the CNIL is needed if more than 1000 patients are included.

\subsection{Culture}

One antral and one corpus biopsy specimen were taken for bacteriological analysis. The two biopsies were homogenized in a glass Griffiths tube in $0.5 \mathrm{~mL}$ of brain heart 
infusion medium (bioMérieux, Marcy l'Etoile, France). One part of the suspension was plated on Schaedler agar with vitamin K1 and 5\% sheep's blood (Becton Dickinson, Heidelberg, Germany) and the PYL selective medium (bioMérieux, Marcy l'Etoile, France). After inoculation, plates were immediately incubated at $37{ }^{\circ} \mathrm{C}$ for 10 days under wet and microaerophilic conditions.

The other part of the suspension was kept for molecular methods.

H. pylori growth was monitored starting from day 3. Positive cultures were confirmed as $H$. pylori on the basis of Gram staining, colony morphology (small, round colonies) and positive oxidase, catalase and urease reactions. Strains were stored at $-80{ }^{\circ} \mathrm{C}$ in $3 \mathrm{~mL}$ meat-liver media (bioMérieux, Marcy l'Etoile, France) with $0.3 \mathrm{~mL}$ glycerol added.

\subsection{Histology}

Three antral and three corpus specimen were formalin-fixed and paraffin-embedded. Tissue sections were stained with Giemsa for detection of Helicobacter-like organisms and hematoxylin-eosin (H\&E) for histological grading. Immunohistochemical staining was performed only in cases of severe gastritis or suspected mucosa-associated lymphoid tissue lymphoma or gastric cancer. An experienced expert pathologist read the slides according to the routine pathology laboratory workflow. Therefore, slides were not reviewed by another pathologist in case of discordant results with culture/molecular methods. The degree of inflammation (mononuclear cell infiltration), activity (neutrophil infiltration), gastric glandular atrophy and intestinal metaplasia was assessed according to the updated Sydney classification as follows: 0 , absent; 1, mild: 2, moderate; 3, marked [11]. Presence of erosions or lymphoid follicles was noted. Then, patients were classified into 3 categories: "normal histology" (grade 0), "mild and moderate gastritis" (grade 1-2), "severe gastritis and gastric cancer" (grade 3 ).

\subsection{Detection of H. pylori by $q P C R$}

An in-house qPCR assay was used to detect both the presence of $H$. pylori and point mutations conferring clarithromycin resistance as described [12]. From the homogenized suspension, DNA was isolated by using a QIAamp DNA mini kit (Qiagen SA, Courtaboeuf, France). A 267-bp fragment of the $H$. pylori 23S rRNA gene was amplified with primers for HPYS and HPYA (Table 1) using the LightCycler thermocycler (Roche Diagnostics, Neuilly sur Seine, France). The specificity of the qPCR method was evaluated by using different microorganisms (Enterococcus faecalis, Pseudomonas aeruginosa, coagulase-negative Staphylococcus, Candida albicans, Escherichia coli, Klebsiella pneumoniae) for which qPCR testing remained negative. The qPCR testing was also negative for Campylobacter spp. Each run included positive and negative controls, the former prepared from $10^{-2}, 10^{-4}$, and $10^{-6}$ dilutions of $45 \mu \mathrm{g} / \mathrm{mL}$ DNA from $H$. pylori strain H37Rv, and the latter consisting of sterile water. Quality control was acceptable when the negative control had an undetectable cycle threshold $(\mathrm{Ct})$ and the $10^{-2}, 10^{-4}$, and $10^{-6}$ dilutions of $H$. pylori DNA McFarland 1 had Ct values of 17-19, 19-27, and 27-33, respectively [13].

\subsection{Confirmation of $H$. pylori Detection by Amplifying glmM}

H. pylori-specific glmM PCR was systematically performed to confirm qPCR results [14]. A 294-bp fragment internal to $g l m M$ was amplified as described (Table 1). Molecular techniques (23S rRNA confirmed by $g \operatorname{lmM}$ ) were considered the gold standard in this study for diagnosis of H. pylori infection [15].

\section{6. cagA Status}

The $\operatorname{cag} A$ status was determined on all DNA extracts by a specific PCR with a set of primers for $c a g F$ and $c a g R$ (Table 1). A 349-bp fragment from the middle conservative region of the $\operatorname{cag} A$ gene was amplified in $\operatorname{cag} A$-positive strains [16]. An empty-site assay with primers 2 and 25 (Table 1), which flank the left and right ends of the cag-PAI, was used 
to confirm the absence of the pathogenicity island cag-PAI in cagA-negative strains [17]. PCR products for each reaction were analyzed by gel electrophoresis.

Table 1. Primer sequences used in this study.

\begin{tabular}{|c|c|c|c|c|c|}
\hline Gene & Target Site & Primer & Primer Sequences $\left(5^{\prime}-3^{\prime}\right)$ & $\begin{array}{l}\text { PCR Product } \\
\text { Size }(\mathrm{pb})\end{array}$ & References \\
\hline \multirow{2}{*}{$23 \mathrm{~S}$ rRNA } & \multirow{2}{*}{ Domaine $\mathrm{V}$} & HPY-S & AGGTTAAGAGGATGCGTCAGTC & \multirow{2}{*}{267} & \multirow{2}{*}{ [12] } \\
\hline & & HPY-AS & CGCATGATATTCCCATTAGCAGT & & \\
\hline \multirow{2}{*}{$g \operatorname{lm} M$} & \multirow{2}{*}{$g \operatorname{lm} M$} & glmM S & GGATAAGCTTTTAGGGGTGTTAGGGG & \multirow{2}{*}{294} & \multirow{2}{*}{ [14] } \\
\hline & & glmM AS & GCTTACTTTCTAACACTAACGCGC & & \\
\hline \multirow{12}{*}{$\operatorname{cag} A$} & \multirow{2}{*}{$\operatorname{cag} A$ constant region } & cagA-F & GATAACAGGCAAGCTTTTGAGG & \multirow{2}{*}{349} & \multirow{2}{*}{ [16] } \\
\hline & & cagA-R & CTGCAAAAGATTGTTTGGCAGA & & \\
\hline & \multirow{2}{*}{ Empty-site } & 2 & ACATTTTGGCTAAATAAACGCTG & \multirow{2}{*}{360} & \multirow{2}{*}{ [17] } \\
\hline & & 25 & TCATGCGAGCGGCGATGTG & & \\
\hline & $\begin{array}{l}\text { Forward for all EPIYA } \\
\text { motifs }\end{array}$ & $\operatorname{cag} \mathrm{A} 28 \mathrm{~F}$ & TTCTCAAAGGAGCAATTGGC & & \multirow{5}{*}{ [18] } \\
\hline & EPYIA-A & cagA-P1C & GTCCTGCTTTCTTTTTATTAACTTKAGC & 264 & \\
\hline & EPYIA-B & cagA-P2CG & TTTAGCAACTTGAGCGTAAATGGG & 309 & \\
\hline & EPIYA-B & cagA-P2TA & TTTAGCAACTTGAGTATAAATGGG & 309 & \\
\hline & EPYIA-C et D & cagA-P3E & ATCAATTGTAGCGTAAATGGG & 468 & \\
\hline & EPIYA-D & cagA-pD & TTGATTTGCCTCATCAAAATC & 486 & [19] \\
\hline & \multirow[t]{2}{*}{$\operatorname{cag} A$ variable region } & cagA2530S & $\begin{array}{c}\text { GTTAARAATRGTGTRAAYGG } \\
(R=A \text { ou } G \text { and } Y=T \text { ou } C)\end{array}$ & \multirow[t]{2}{*}{ Variable } & \multirow[t]{2}{*}{ [20] } \\
\hline & & cagA3000AS & TTTAGCTTCTGATACCGC & & \\
\hline \multirow{4}{*}{ vacA } & \multirow{2}{*}{ «S» region } & VA1F & ATGGAAATACAACAAACACAC & \multirow{2}{*}{$\begin{array}{l}259(\mathrm{~s} 1) \\
286(\mathrm{~s} 2)\end{array}$} & \multirow{2}{*}{ [16] } \\
\hline & & VA1R & CTGCTTGAATGCGCCAAAC & & \\
\hline & \multirow{2}{*}{ «m» region } & VAGF & CAATCTGTCCAATCAAGCGAG & \multirow{2}{*}{$\begin{array}{l}570(\mathrm{~m} 1) \\
645(\mathrm{~m} 2)\end{array}$} & \multirow{2}{*}{ [16] } \\
\hline & & VAGR & GCGTCTAAATAATTCCAAGG & & \\
\hline
\end{tabular}

\subsection{Characterization of the C-Terminal Variable Region by EPIYA Motifs}

To assess the number and type of EPIYA motifs in cagA-positive samples, separate PCR reactions involved using a common forward primer for $c a g A 28 \mathrm{~F}$ and the reverse primers for cagA-P1C, cagA-P2TA and cagA-P2CG (1:1 mixture) and cagA-P3E (Table 1) for amplifying EPIYA-A, -B, -C and -D, respectively [18]. To distinguish between EPIYA-C and $-\mathrm{D}$, another reaction with primers for $c a g A 28 \mathrm{~F}$ and cagA-pD (Table 1) was performed to identify the presence of an EPIYA-D motif [19]. Resulting patterns were visualized by ethidium bromide staining after electrophoresis on a 1.5\% agarose gel. In case of inconclusive PCR genotyping and for some randomly selected cag $A$-positive samples, the $3^{\prime} \operatorname{cag} A$ variable region was amplified, then sequenced with the primers for cagA2530S and cagA3000AS (Table 1) as described [20]. All in-house PCR amplicon sequencing was performed by a custom sequencing service (Eurofins MWG Operon, Ebersberg, Germany).

\section{8. vacA Genotyping}

Polymorphisms in the signal (s-) and middle (m-) region of vac $A$ were determined as described [16]. Typing of the vacA s- sequence region was characterized by using a set of primers for VA1F and VA1R (Table 1), which resulted in generating fragments of $259 \mathrm{bp}$ for type s1 variants or fragments of $286 \mathrm{bp}$ for type s2 variants. The vacA mregion was typed by using a set of primers for VAG-F and VAG-R to amplify a 570-bp 
product for $\mathrm{m} 1$ and 645 -bp product for $\mathrm{m} 2$ (Table 1). PCR products for each reaction were analyzed by gel electrophoresis.

\subsection{Statistical Analysis}

The online software VassarStats (Richard Lowry) was used for data analysis. Frequencies of categorical variables were calculated, and Fisher's exact test, chi-square test or Student $t$ test was used to determine differences between groups. Statistical significance was set at $p<0.05$.

\section{Results}

\subsection{Patients and H. pylori Infection}

During the study period, 1540 adults (744 men and 796 women; mean age $52.6 \pm 16.5$ years (16 years-94 years)) and 504 children ( 261 boys and 243 girls, mean age $8.4 \pm 4.4$ years ( 8 months-17 years)) underwent endoscopy.

H. pylori culture was positive in 382 biopsies: 346/1540 (22.4\%) from adults and 36/504 (7.1\%) from children. The molecular techniques (in-house qPCR confirmed by the $g \operatorname{lmM}$ PCR) proved infection in 513 biopsies: 453/1540 (29.4\%) from adults and 60/504 (11.9\%) from children. Therefore, H. pylori infection was proved only by molecular methods in 107 adults and 24 children.

H. pylori positivity rates were significantly higher in adults than children $(p<0.001)$, but rates did not differ by sex or age within each group. With the in-house qPCR confirmed by the $g \operatorname{lm} M$ PCR as the reference, culture showed a sensitivity and specificity of $74.4 \%$ and $100 \%$, respectively. When considering only high-bacterial-load biopsies (i.e., qPCR $\mathrm{Ct}<30$ ), the sensitivity of culture increased to $93.4 \%$. Most biopsies (105/131, 80.1\%) with a false negative culture had low bacterial load (i.e., qPCR Ct $\geq 30$ ) (Table 2).

Table 2. Association of bacterial load by qPCR with biopsy culture results $(n=513)$ and Helicobacter pylori histology detection ( $n=338,278$ adults and 60 children).

\begin{tabular}{|c|c|c|c|}
\hline & \multicolumn{2}{|c|}{ Bacterial Load (qPCR Ct Values) } & \multirow[b]{2}{*}{$p$-Value } \\
\hline & $\begin{array}{c}\text { High }(\mathrm{Ct}<30) \\
n(\%)\end{array}$ & $\begin{array}{c}\text { Low }(\mathrm{Ct} \geq 30) \\
n(\%)\end{array}$ & \\
\hline \multicolumn{4}{|c|}{ Culture $(n=513) *$} \\
\hline Positive & $368(93.4)$ & $14(11.8)$ & $<0.001^{\Phi}$ \\
\hline Negative & $26(6.6)$ & $105(88.2)$ & \\
\hline Total & $394(100)$ & $119(100)$ & \\
\hline \multicolumn{4}{|c|}{ H. pylori histology detection $(n=338)^{* *}$} \\
\hline Positive & $234(92.5)$ & $14(16.4)$ & $<0.001^{\Phi}$ \\
\hline Negative & $19(7.7)$ & $71(83.5)$ & \\
\hline Total & $253(100)$ & 85 (100) & \\
\hline
\end{tabular}

\subsection{Histology}

Histology reports were available for only $338 \mathrm{H}$. pylori-positive patients: 278 adults attending the gastroenterology unit of Cochin Hospital and 60 children attending the Saint Vincent de Paul Hospital in Lille. As compared with molecular techniques, Helicobacter-like organisms histology detection had a sensitivity of $73.3 \%(248 / 338)$; the specificity could not be calculated because histology data for only $H$. pylori-positive patients were collected. Logically, direct examination with Giemsa staining was more sensitive $(234 / 253,92.5 \%)$ in biopsies with high bacterial load (qPCR $\mathrm{Ct}<30$ ), whereas a low bacterial load (qPCR 
$\mathrm{Ct} \geq 30)$ was associated with absence of Helicobacter-like organisms on histology $(71 / 85$, $83.5 \%$ ) (Table 2).

The distribution of adults and children infected by Helicobacter-like organisms by histology grading is shown in Table 3. Among the 60 children, $18(30 \%)$ had normal findings, $28(46.6 \%)$ mild or moderate gastritis and $14(23.3 \%)$ severe gastritis. In the same way, among the 278 adults, $23(8.2 \%)$ had normal findings, $204(73.3 \%)$ mild or moderate gastritis and $51(18.3 \%)$ severe gastritis including 2 with gastric cancers. For both groups, the presence of Helicobacter-like organisms on histology sections was significantly associated with gastritis severity: 3/41 (7.3\%) with normal findings vs. 191/232 (82.3\%) and $54 / 65(83 \%)$ with moderate and severe gastritis, respectively $(p<0.01)$ (Table 3$)$. Of note, high bacterial load (qPCR Ct $<30$ ) was significantly associated with gastritis severity: $5 / 41(12.2 \%)$ with normal findings vs. $193 / 232(83.2 \%)$ and 56/65 (86.1\%) with moderate and severe gastritis, respectively $(p<0.01)$ (Table 3$)$.

Table 3. Association between presence of H. pylori on histology, bacterial load (qPCR), cagA status of the strain and severity of histology lesions in $338 \mathrm{H}$. pylori-positive biopsies (278 adults and 60 children).

\begin{tabular}{|c|c|c|c|c|}
\hline & \multicolumn{3}{|c|}{ Histology Grading } & \multirow[b]{2}{*}{$p$-Value } \\
\hline & $\begin{array}{c}\text { Normal } \\
n(\%)\end{array}$ & $\begin{array}{l}\text { Mild and Moderate } \\
\text { Gastritis } n(\%)\end{array}$ & $\begin{array}{c}\text { Severe Gastritis/Gastric } \\
\text { Cancer } n(\%)\end{array}$ & \\
\hline \multicolumn{5}{|l|}{ Age group } \\
\hline Adults $(n=278)$ & $23(56.1)$ & $204(87.9)$ & $51(78.5)$ & - \\
\hline Children $(n=60)$ & $18(43.9)$ & $28(12.1)$ & $14(21.5)$ & \\
\hline Total & $41(100)$ & $232(100)$ & $65(100)$ & \\
\hline \multicolumn{5}{|c|}{ H. pylori histology detection } \\
\hline Positive & $3(7.3)$ & $191(82.3)$ & $54(83)$ & $<0.001^{\Phi}$ \\
\hline Negative & $38(92.7)$ & $41(17.7)$ & $11(16.9)$ & \\
\hline Total & $41(100)$ & $232(100)$ & $65(100)$ & \\
\hline \multicolumn{5}{|c|}{ Bacterial load (qPCR Ct values) } \\
\hline $\operatorname{High}(\mathrm{Ct}<30)$ & $5(12.2)$ & $193(83.2)$ & $56(86.1)$ & $<0.001^{\Phi}$ \\
\hline Low $(\mathrm{Ct} \geq 30)$ & $36(87.8)$ & $39(16.8)$ & $9(13.8)$ & \\
\hline Total & $41(100)$ & $232(100)$ & $65(100)$ & \\
\hline \multicolumn{5}{|l|}{$\operatorname{cag} A$ status } \\
\hline Positive & $3(7.3)$ & $63(27.1)$ & $30(46.1)$ & $<0.001^{\Phi}$ \\
\hline Negative & $38(92.7)$ & $159(68.5)$ & $34(52.3)$ & \\
\hline Undetermined & $0(0)$ & $10(4.3)$ & $1(1.5)$ & \\
\hline Total & $41(100)$ & $232(100)$ & $65(100)$ & \\
\hline
\end{tabular}

\section{3. cagA Status and Genotype}

The cagA status was successfully assessed in 495/513 H. pylori-positive biopsies (435/453 from adults and 60/60 from children) and was undetermined for 18 adults. Among these 495 biopsies, 158 (31.9\%) were cagA-positive (151 from adults and 7 from children). Therefore, the prevalence of the cagA gene was significantly lower in children than adults $(11.6 \%$ vs. $34.7 \% ; p<0.001)$. The absence of cag-PAI was confirmed by empty-site PCR in all cagA-negative samples. Among cagA-positive isolates, all EPIYA motif patterns were related to the Western type, harboring the $\mathrm{ABC}(n=122,80.8 \%), \mathrm{ABCC}(n=12), \mathrm{BC}$ $(n=6), \mathrm{AC}(n=6), \mathrm{ABC}+\mathrm{ABCC}(n=2), \mathrm{AB}(n=1), \mathrm{ACC}(n=1)$ and $\mathrm{BCC}(n=1)$ motifs in adults and $\mathrm{ABC}(n=6,85.7 \%)$ and $\mathrm{AC}(n=1)$ motifs in children. For both groups, cagA status was significantly associated with gastritis severity: $3 / 41$ (7.3\%) with normal findings 
vs. $63 / 232(27.1 \%)$ and $30 / 65(46.1 \%)$ with moderate and severe gastritis, respectively $(p<0.01)$ (Table 3).

\section{4. vacA Genotype and Association with cagA Status}

Data on vacA genotyping were available for only 292 and $30 \mathrm{H}$. pylori-positive biopsies from adults and children, respectively. The most frequent allele combination was $1 \mathrm{~m} 1$ $(51.2 \%, 165 / 322)$, followed by $s 2 m 2(31.7 \%, 102 / 322)$, s $1 m 2(12.1 \%, 39 / 322)$ and $s 2 m 1(5.0 \%$, $16 / 322)$. The distribution of vacA allelic variants was homogeneous among adults and children, and no mixed infection with different variants was found. We found a significant association between $v a c A$ allele combinations and $c a g A$ status: $61.8 \%(102 / 163)$ of $s 1 m 1$ variants were $\operatorname{cag} A$-positive and $93.1 \%(95 / 102)$ of $s 2 m 2$ variants were $\operatorname{cag} A$-negative $(p<0.001)$.

3.5. Association between Presence of H. pylori and Histology, Bacterial Load (qPCR), cagA Status of the Strain and Severity of Histology Lesions

We observed a significant association between the severity of histology lesions and both the presence of Helicobacter-like organisms on histology and bacterial load expressed by qPCR Ct values $(7.3 \%$ to $83 \%$ and $12.2 \%$ to $86.1 \%$, respectively, $p<0.001$, for normal histology findings to severe gastritis) (Table 3). The prevalence of $c a g A$ gene increased significantly from $7.3 \%$ (3/41) with normal histology findings to $46.1 \%(30 / 65)$ with severe gastritis/gastric cancer (Table 3). Of note, one patient in two with gastric cancer carried a cagA-negative strain and all of the children with normal histology findings carried a $\operatorname{cag} A$-negative strain.

\subsection{Association between a Positive Culture, Bacterial Load (qPCR), Presence of H. pylori on Histology and cagA Status of the Strain}

We found a significant association between the presence of Helicobacter-like organisms on histology, a positive culture and the cagA status of the strain (all $p<0.001$ ) (Table 4 ). Indeed, as compared with $\operatorname{cag} A$-negative isolates, $\operatorname{cag} A$-positive strains were more often positive on histology (91.7\% vs. $64.5 \%)$ and culture (94.3\% vs. $64.7 \%)$ and had high bacterial load (94.9\% vs. 67.3\%). Notably, 76/84 (90.5\%) biopsies H. pylori-positive by PCR and negative on histology had a cag $A$-negative status. In the same way, 119/128 (92.9\%) biopsies $H$. pylori-positive by PCR and negative culture had a cag $A$-negative status. In summary, $H$. pylori bacterial load, expressed by qPCR Ct values, was significantly associated with the cagA status of strains $(150 / 158,94.9 \%)$, and biopsies with high bacterial load (qPCR Ct $<30$ ) were cag $A$-positive, $(p<0.001)$. (Table 4$)$. Conversely, in 119 biopsies with low bacterial load (qPCR $C t \geq 30)$, only eight (6.7\%) were positive for $\operatorname{cag} A$. Overall, cagA-negative strains were associated with a low bacterial load $(110 / 119,92.4 \%)$, negative $H$. pylori histology $(82 / 90,91.1 \%)$ and negative culture findings $(119 / 131,90 \%)$.

Table 4. Association between culture positivity, bacterial load (qPCR Ct values), presence of $H$. pylori on histology and $\operatorname{cag} A$ status of the strain.

\begin{tabular}{lcccc}
\hline & \multicolumn{3}{c}{ cagA Status } & \\
\cline { 2 - 4 } & $\begin{array}{c}\text { Positive } \\
\boldsymbol{n} \mathbf{( \% )}\end{array}$ & $\begin{array}{c}\text { Negative } \\
\boldsymbol{n} \mathbf{( \% )}\end{array}$ & $\begin{array}{c}\text { Undetermined } \\
\boldsymbol{n} \mathbf{( \% )}\end{array}$ & $p$-Value \\
\hline Culture $(n=513) *$ & $149(94.3)$ & $218(64.7)$ & $15(83.3)$ & $<0.001^{\Phi}$ \\
\hline Positive & $9(5.7)$ & $119(35.3)$ & $3(16.7)$ & \\
\hline Negative & $158(100)$ & $337(100)$ & $18(100)$ & $<0.0011^{\Phi}$ \\
\hline Total & $150(94.9)$ & $227(67.3)$ & $17(94.4)$ & \\
\hline Bacterial load $(n=513) *$ &
\end{tabular}


Table 4. Cont.

\begin{tabular}{lcccc}
\hline & \multicolumn{3}{c}{ cagA Status } & \\
\cline { 2 - 4 } & $\begin{array}{c}\text { Positive } \\
\boldsymbol{n} \mathbf{( \% )}\end{array}$ & $\begin{array}{c}\text { Negative } \\
\boldsymbol{n} \mathbf{( \% )}\end{array}$ & $\begin{array}{c}\text { Undetermined } \\
\boldsymbol{n} \mathbf{( \% )}\end{array}$ & $p$-Value \\
\hline Low $(\mathrm{Ct} \geq 30)$ & $8(5.1)$ & $110(32.7)$ & $1(5.6)$ & \\
\hline Total & $158(100)$ & $337(100)$ & $18(100)$ & $<0.001{ }^{\Phi}$ \\
\hline H. pylori histology detection in 338 & $88(91.7)$ & $149(64.5)$ & $11(100)$ & \\
\hline Positive & $8(8.3)$ & $82(35.5)$ & $0(0)$ & \\
\hline Negative & $96(100)$ & $231(100)$ & $11(100)$ & \\
\hline Total & &
\end{tabular}

$\Phi$ chi-square test; $\mathrm{Ct}=$ cycle threshold; ${ }^{*}$ Culture and bacterial load were evaluated in $513 \mathrm{H}$. pylori-positive biopsies by comparison to the gold standard considered in this study (23S rRNA qPCR confirmed by glmM amplification). ${ }^{* *}$ H. pylori histology detection was evaluated in $338 \mathrm{H}$. pylori-positive biopsies for which histology reports were available.

\section{Discussion}

Reliable and accurate diagnostic methods are mandatory for the effective management of gastroduodenal diseases associated with $H$. pylori infection. PCR-based diagnosis targeting at least two conserved genes can be considered the gold standard [15]. We evaluated the performance of both histology and culture for detecting $H$. pylori infection, taking as the gold standard molecular techniques (23S rRNA confirmed by $g \operatorname{lm} M$ ).

The sensitivity of Helicobacter-like organisms histology detection by Giemsa staining was lower (73.3\%) than in previous reports [21] but increased up to $94.2 \%$ in biopsies with high bacterial load (qPCR $\mathrm{Ct}<30$ ). Histology performance depends on the pathologist's expertise, stain methods, prior antibiotics or PPI use and variable bacterial density according to the sampling site [21-23]. A real gap may exist between international guidelines and daily practice, with continued use of PPIs at endoscopy or one-region biopsy sampling, which can increase the likelihood of missing active infection by histology [24]. In line with a previous study in a pediatric population, in our study, the severity of gastritis was directly related to the presence of Helicobacter-like organisms on histology and high bacterial load by qPCR ( $\mathrm{Ct}<30$ ) (Table 3) [25]. We confirmed that a false negative diagnosis by histology staining may be linked to biopsies with few Helicobacter-like organisms [26], in agreement with the findings of Benoit et al., stating that $H$. pylori is present only in cases of active gastritis and is always on the standard staining with H-E (in 94\% of the cases) [27]. The authors concluded that it is not necessary to systematically perform a complementary histoor immuno-histochemical technique on all gastric biopsies [27]. In cases of low bacterial load, H. pylori infection can be missed if histology is the only test performed.

H. pylori culture from gastric biopsy specimens has high specificity, but its sensitivity shows significant variations $[28,29]$. With our two-target PCR as a reference, culture showed perfect specificity $(100 \%)$ and suboptimal sensitivity $(74.4 \%)$. A previous study demonstrated increased sensitivity up to $90 \%$ if culture is performed under optimal conditions (i.e., fastidious growth requirements, rapid transportation of gastric biopsies to the laboratory) [30]. A false negative culture could be highly associated with poor bacterial load detected by qPCR [25]. Our findings of low sensitivity of histology and culture for specimens with low bacterial load are supported by a few studies of $H$. pylori gastric atrophy [31,32]. Indeed, density of $H$. pylori in the stomach mucosa decreases and may disappear completely during the late stages of atrophy, which is associated with markedly lower sensitivity of histology, culture and urease tests.

Molecular testing applied directly to biopsy specimens provides a fast and accurate diagnosis. One of the advantages is the assessment of all strains present in the specimen because some may grow on culture medium better than others [33]. This approach offers the possibility to evaluate bacterial quantification and detect antimicrobial resistance (mainly clarithromycin) and virulence factors. 
In our adults, the $\operatorname{cag} A$ gene prevalence was $34.1 \%$, in agreement with previous European findings, ranging from $30 \%$ to $60 \%$ [8], but lower than in other French findings, from $53 \%$ to $63 \%[34,35]$. We found significantly lower cagA positivity in children than adults $(p<0.001)$, as previously observed [36]. By using immunoblotting, Rocha et al. found the detection of antibodies to the CagA antigen significantly higher in older children and hypothesized that increased $\operatorname{cag} A$ prevalence by age in children may reflect an evolutionary modification to achieve successful colonization during transmission [37]. The EPIYA-ABC motif was the most common in adults (80.5\% of strains) as in children $(85.7 \%)$ in our study, in line with prior reports from Europe [36]. Conversely, in East Asian countries, a high frequency of $H$. pylori strains with the more virulent EPIYA-D motif has been described in symptomatic children [38].

In our study, $\operatorname{cag} A$ positivity was significantly associated with increased severity of histology lesions, with a prevalence increasing from $7.3 \%$ in patients with normal findings, $27.1 \%$ in those with mild/moderate gastritis and $46.1 \%$ in those with severe gastritis $(p<0.001)$. These findings confirm that the histological virulence score is significantly increased in the presence of $\operatorname{cag} A$-positive strains [39-41].

We found all combinations of the vacA $\mathrm{s}$ and $\mathrm{m}$ alleles. The distribution of vacA genotypes was similar to other findings from western Europe, with $\operatorname{sim} 1$ the most prevalent (51.2\%), followed by $s 2 m 2(31.7 \%), s 1 m 2(12.1 \%)$ and $s 2 m 1$ (5.0\%) [42]. The vacA s $1 m 1$ genotype has been associated with severe gastric lesions and increased risk of gastric cancer $[43,44]$. Our study showed that the more severe the histological lesions, the more prevalent the vacA $\operatorname{sim} 1$ allelic combination. However, this association was not significant because of the small number of patients with histology results and vacA genotyping. As previously reported, we confirmed the non-random distribution of genotype combinations of $\operatorname{cag} A$ and vacA: $\operatorname{cag} A$-positive strains were frequently vac $A \operatorname{sim} A$ and $\operatorname{cag} A$-negative strains were frequently vacA s2m2 $(p<0.001)$ [45].

This study is among the first attempts to assess the effects of virulence factors and bacterial load on the performance of diagnostic tests for $H$. pylori infection. Infection with a cagA-positive strain was associated with increased bacterial load $(94.9 \%)$, which resulted in more frequent positive culture $(94.3 \%)$ and Helicobacter-like organisms histology detection (91.7\%). Conversely, cagA detection in strains was negative in $92.4 \%$ of biopsies with low bacterial load, $91.1 \%$ with negative $H$. pylori histology detection and $90 \%$ with negative culture. Some previous studies reported a relation between bacterial load in gastric biopsies or stools and the cagA virulence factor [10,46,47]. In 1996, Atherton et al. postulated that the H. pylori genotype may determine bacterial density, which in turn can determine inflammation level and epithelial injury [48]. Then, Belda et al. suggested that colonization by low virulence strains with slow multiplication in the gastric mucosa may not cause serious epithelial damage [46]. These differences can be linked to the bacterial density, which is itself linked to the presence/absence of CagA. These data may have an impact on the treatment by differentiating infection from colonization.

These hypotheses led to provocative questions. What is the clinical significance of the molecular detection of a low density of cagA-negative $H$. pylori usually missed by histology and conventional culture? Should we consider treating these cases with the same guidelines? Some studies tried to address this latter issue and showed that $\operatorname{cag} A$-negative strains are a potential risk factor for treatment failure and may need a more thorough eradication protocol [49]. Nonetheless, the present study demonstrates that non-optimal sensitivity of culture and $H$. pylori histology determination can also be explained by a low density of $c a g A$-negative $H$. pylori strains and not just poor pre-analytical conditions.

\section{Conclusions}

This study highlights the low sensitivity of conventional techniques (i.e., culture and $H$. pylori histology determination) leading to a false negative diagnosis of $H$. pylori infection if performed alone. Molecular-based techniques, using two different primers, provide an accurate detection of $H$. pylori and can be used to assess bacterial load and the 
virulence potential. $H$. pylori quantification associated with cagA genotyping in routine practice is essential to determine a sensitive and reliable diagnosis, to distinguish an infection from a colonization and to identify high-risk patients allowing management of eradication therapies.

Author Contributions: Conceptualization, N.G. and J.R.; methodology, R.C., N.K., D.L., B.T., V.A. and J.R.; data curation, G.C., A.B., N.G. and M.A.; writing-original draft preparation, N.G and M.A.; writing-review and editing, N.G and J.R. All authors have read and agreed to the published version of the manuscript.

Funding: This research received no external funding.

Informed Consent Statement: Informed consent was obtained from all subjects involved in the study.

Conflicts of Interest: The authors declare no conflict of interest.

\section{References}

1. Mégraud, F.; Lehours, P. Helicobacter pylori Detection and Antimicrobial Susceptibility Testing. Clin. Microbiol. Rev. 2007, 20, 280-322. [CrossRef] [PubMed]

2. Malfertheiner, P.; Megraud, F.; O’Morain, C.A.; Gisbert, J.P.; Kuipers, E.J.; Axon, A.T.; Bazzoli, F.; Gasbarrini, A.; Atherton, J.; Graham, D.Y. European Helicobacter and Microbiota Study Group and Consensus panel. Management of Helicobacter pylori infection-the Maastricht V/Florence Consensus Report. Gut 2017, 66, 6-30. [CrossRef]

3. Espinoza, M.G.C.; Vazquez, R.G.; Mendez, I.M.; Vargas, C.R.; Cerezo, S.G. Detection of the glmM Gene in Helicobacter pylori Isolates with a Novel Primer by PCR. J. Clin. Microbiol. 2011, 49, 1650-1652. [CrossRef] [PubMed]

4. De Reuse, H.; Labigne, A.; Mengin-Lecreulx, D. The Helicobacter pylori ureC gene codes for a phosphoglucosamine mutase. J. Bacteriol. 1997, 179, 3488-3493. [CrossRef]

5. Šterbenc, A.; Jarc, E.; Poljak, M.; Homan, M. Helicobacter pylori virulence genes. World J. Gastroenterol. 2019, $25,4870-4884$. [CrossRef] [PubMed]

6. Yamaoka, Y.; Osato, M.S.; Sepulveda, A.R.; Gutierrez, O.; Figura, N.; Kim, J.G.; Kodama, T.; Kashima, K.; Graham, D.Y. Molecular epidemiology of Helicobacter pylori: Separation of H. pylori from East Asian and non-Asian countries. Epidemiol. Infect. 2000, 124, 91-96. [CrossRef] [PubMed]

7. Ansari, S.; Yamaoka, Y. Helicobacter pylori Virulence Factors Exploiting Gastric Colonization and its Pathogenicity. Toxins 2019, 11, 677. [CrossRef]

8. Markovska, R.; Boyanova, L.; Yordanov, D.; Stankova, P.; Gergova, G.; Mitov, I. Status of Helicobacter pylori cag pathogenicity island (cag PAI) integrity and significance of its individual genes. Infect. Genet. Evol. 2018, 59, 167-171. [CrossRef]

9. González, C.A.; Figueiredo, C.; Lic, B.C.; Ferreira, R.; Pardo, M.L.; Liso, R.J.M.; Alonso, P.; Sala, N.; Capella, G.; Sanz-Anquela, J.M. Helicobacter pylori cagA and vacA Genotypes as Predictors of Progression of Gastric Preneoplastic Lesions: A Long-Term Follow-Up in a High-Risk Area in Spain. Am. J. Gastroenterol. 2011, 106, 867-874. [CrossRef]

10. Khiddi, F.; Abdellahi, M.V.M.; Horma, M.A.; Billoet, A.; Collobert, G.; Amar, A.M.; Nech, H.D.M.; Vadel, E.H.M.; Houmeida, A.; Raymond, J.; et al. Characteristics of Helicobacter pylori strains isolated from Mauritanian patients. Helicobacter 2020, 25 , e12726. [CrossRef]

11. Dixon, M.F.; Genta, R.M.; Yardley, J.H.; Correa, P. Classification and grading of gastritis. The updated Sydney System. International Workshop on the Histopathology of Gastritis, Houston 1994. Am. J. Surg. Pathol. 1996, 20, 1161-1181. [CrossRef]

12. Oleastro, M.; Ménard, A.; Santos, A.; Lamouliatte, H.; Monteiro, L.; Barthélémy, P.; Mégraud, F. Real-Time PCR Assay for Rapid and Accurate Detection of Point Mutations Conferring Resistance to Clarithromycin in Helicobacter pylori. J. Clin. Microbiol. 2003, 41, 397-402. [CrossRef]

13. Bazin, T.; Mfondi, A.N.; Julie, C.; Émile, J.-F.; Raymond, J.; Lamarque, D. Contribution of genetic amplification by PCR for the diagnosis of Helicobacter pylori infection in patients receiving proton pump inhibitors. United Eur. Gastroenterol. J. 2018, 6, 1267-1273. [CrossRef]

14. Kansau, I.; Raymond, J.; Bingen, E.; Courcoux, P.; Kalach, N.; Bergeret, M.; Braimi, N.; Dupont, C.; Labigne, A. Genotyping of Helicobacter pylori isolates by sequencing of PCR products and comparison with the RAPD technique. Res. Microbiol. 1996, 147, 661-669. [CrossRef]

15. Patel, S.K.; Pratap, C.B.; Jain, A.K.; Gulati, A.K.; Nath, G. Diagnosis of Helicobacter pylori: What should be the gold standard? World J. Gastroenterol. 2014, 20, 12847-12859. [CrossRef] [PubMed]

16. Yamaoka, Y.; Kodama, T.; Gutierrez, O.; Kim, J.G.; Kashima, K.; Graham, D.Y. Relationship between Helicobacter pylori iceA, cagA, and vacA Status and Clinical Outcome: Studies in Four Different Countries. J. Clin. Microbiol. 1999, 37, 2274-2279. [CrossRef]

17. Akopyants, N.S.; Clifton, S.W.; Kersulyte, D.; Crabtree, J.E.; Youree, B.E.; Reece, C.A.; Bukanov, N.O.; Drazek, E.S.; Roe, B.A.; Berg, D.E. Analyses of the cag pathogenicity island of Helicobacter pylori. Mol. Microbiol. 2002, 28, 37-53. [CrossRef] 
18. Argent, R.H.; Zhang, Y.; Atherton, J.C. Simple Method for Determination of the Number of Helicobacter pylori CagA VariableRegion EPIYA Tyrosine Phosphorylation Motifs by PCR. J. Clin. Microbiol. 2005, 43, 791-795. [CrossRef] [PubMed]

19. Jones, K.R.; Joo, Y.M.; Jang, S.; Yoo, Y.-J.; Lee, H.S.; Chung, I.-S.; Olsen, C.H.; Whitmire, J.M.; Merrell, D.S.; Cha, J.-H. Polymorphism in the CagA EPIYA Motif Impacts Development of Gastric Cancer. J. Clin. Microbiol. 2009, 47, 959-968. [CrossRef] [PubMed]

20. Panayotopoulou, E.G.; Sgouras, D.N.; Papadakos, K.; Kalliaropoulos, A.; Papatheodoridis, G.; Mentis, A.F.; Archimandritis, A.J. Strategy To Characterize the Number and Type of Repeating EPIYA Phosphorylation Motifs in the Carboxyl Terminus of CagA Protein in Helicobacter pylori Clinical Isolates. J. Clin. Microbiol. 2006, 45, 488-495. [CrossRef] [PubMed]

21. Lee, J.Y.; Kim, N. Diagnosis of Helicobacter pylori by invasive test: Histology. Ann. Transl. Med. 2015, 3, 3. [CrossRef]

22. El-Zimaity, H.M.; Graham, D.Y.; Al-Assi, M.T.; Malaty, H.; Karttunen, T.J.; Huberman, R.M.; Genta, R.M. Interobserver variation in the histopathological assessment of Helicobacter pylori gastritis. Hum. Pathol. 1996, 27, 35-41. [CrossRef]

23. Lee, H.-C.; Huang, T.-C.; Lin, C.-L.; Chen, K.-Y.; Wang, C.-K.; Wu, D.-C. Performance of RoutineHelicobacter pyloriInvasive Tests in Patients with Dyspepsia. Gastroenterol. Res. Pract. 2013, 2013, 184806. [CrossRef] [PubMed]

24. El-Zimaity, H.; Serra, S.; Szentgyorgyi, E.; Vajpeyi, R.; Samani, A. Gastric biopsies: The gap between evidence-based medicine and daily practice in the management of gastric Helicobacter pylori infection. Can. J. Gastroenterol. 2013, 27, e25-e30. [CrossRef]

25. Kalach, N.; Gosset, P.; Dehecq, E.; Decoster, A.; Spyckerelle, C.; Papadopolos, S.; Dupont, C.; Raymond, J. Usefulness of Gastric Biopsy-Based Real-Time Polymerase Chain Reaction for the Diagnosis of Helicobacter pylori Infection in Children. J. Pediatr. Gastroenterol. Nutr. 2015, 61, 307-312. [CrossRef]

26. Wang, X.I.; Zhang, S.; Abreo, F.; Thomas, J. The role of routine immunohistochemistry for Helicobacter pylori in gastric biopsy. Ann. Diagn. Pathol. 2010, 14, 256-259. [CrossRef]

27. Benoit, A.; Hoyeau, N.; Fléjou, J.F. Diagnosis of Helicobacter pylori infection on gastric biopsies: Standard stain, special stain or immunohistochemistry? Ann. Pathol. 2018, 38, 363-369. [CrossRef]

28. Loffeld, R.J.L.F.; Stobberingh, E.; Flendrig, J.A.; Arends, J.W.; Loffeld, R.J.L.F.; Stobberingh, E.; Flendrig, J.A.; Arends, J.W. Helicobacter pylori in gastric biopsy specimens. Comparison of culture, modified Giemsa stain, and immunohistochemistry. A retrospective study. J. Pathol. 1991, 165, 69-73. [CrossRef]

29. Grove, D.I.; Koutsouridis, G.; Cummins, A.G. Comparison of culture, histopathology and urease testing for the diagnosis of Helicobacter pylori gastritis and susceptibility to amoxycillin, clarithromycin, metronidazole and tetracycline. Pathology 1998, 30, 183-187. [CrossRef]

30. Hirschl, A.M.; Makristathis, A. Methods to Detect Helicobacter pylori: From Culture to Molecular Biology. Helicobacter 2007, 12 (Suppl. 2), 6-11. [CrossRef]

31. Lopes, A.I.; Vale, F.F.; Oleastro, M. Helicobacter pylori infection-recent developments in diagnosis. World J. Gastroenterol. 2014, 20, 9299-9313. [CrossRef] [PubMed]

32. Calvet, X.; Lehours, P.; Lario, S.; Mégraud, F. Diagnosis of Helicobacter pylori infection. Helicobacter 2010, 15 (Suppl. S1), 7-13. [CrossRef]

33. Park, C.-Y.; Kwak, M.; Gutierrez, O.; Graham, D.Y.; Yamaoka, Y. Comparison of Genotyping Helicobacter pylori Directly from Biopsy Specimens and Genotyping from Bacterial Cultures. J. Clin. Microbiol. 2003, 41, 3336-3338. [CrossRef]

34. Broutet, N.; Marais, A.; Lamouliatte, H.; de Mascarel, A.; Samoyeau, R.; Salamon, R.; Mégraud, F. cagA Status and Eradication Treatment Outcome of Anti- Helicobacter pylori Triple Therapies in Patients with Nonulcer Dyspepsia. J. Clin. Microbiol. 2001, 39, 1148-1151. [CrossRef]

35. Audibert, C.; Janvier, B.; Grignon, B.; Salaüna, L.; Burucoa, C.; Lecron, J.-C.; Fauchère, J.-L. Correlation between IL-8 induction, cagA status and vacA genotypes in 153 French Helicobacter pylori isolates. Res. Microbiol. 2000, 151, 191-200. [CrossRef]

36. Sgouras, D.N.; Panayotopoulou, E.G.; Papadakos, K.; Martinez-Gonzalez, B.; Roumbani, A.; Panayiotou, J.; VanvlietConstantinidou, C.; Mentis, A.F.; Roma-Giannikou, E. CagA and VacA Polymorphisms Do Not Correlate with Severity of Histopathological Lesions in Helicobacter pylori -Infected Greek Children. J. Clin. Microbiol. 2009, 47, 2426-2434. [CrossRef] [PubMed]

37. Rocha, G.A.; Oliveira, A.M.R.; Queiroz, D.M.M.; Carvalho, A.S.T.; Nogueira, A.M.M.F. Immunoblot Analysis of Humoral Immune Response to Helicobacter pylori in Children with and without Duodenal Ulcer. J. Clin. Microbiol. 2000, 38, 1777-1781. [CrossRef]

38. Li, J.; Ou, Z.; Wang, F.; Guo, Y.; Zhang, R.; Zhang, J.; Li, P.; Xu, W.; He, Y. Distinctiveness of thecagAGenotype in Children and Adults with Peptic Symptoms in South China. Helicobacter 2009, 14, 248-255. [CrossRef] [PubMed]

39. Figueiredo, C.; Van Doorn, L.-J.; Nogueira, C.; Soares, J.M.; Pinho, C.; Figueira, P.; Quint, W.G.V.; Carneiro, F. Helicobacter pylori genotypes are associated with clinical outcome in Portuguese patients and show a high prevalence of infections with multiple strains. Scand. J. Gastroenterol. 2001, 36, 128-135. [CrossRef] [PubMed]

40. Kalaf, E.A.; Al-Khafaji, Z.M.; Yassen, N.Y.; Al-Abbudi, F.A.; Sadwen, S.N. Study of the cytoxin-associated gene a (CagA gene) in Helicobacter pylori using gastric biopsies of Iraqi patients. Saudi J. Gastroenterol. 2013, 19, 69-74. [CrossRef]

41. Diab, M.; Shemis, M.; Gamal, D.; El-Shenawy, A.; El-Ghannam, M.; El-Sherbini, E.; Saber, M. Helicobacter pylori Western cagA genotype in Egyptian patients with upper gastrointestinal disease. Egypt. J. Med. Hum. Genet. 2018, 19, 297-300. [CrossRef]

42. Link, A.; Langner, C.; Schirrmeister, W.; Habendorf, W.; Weigt, J.; Venerito, M.; Tammer, I.; Schlüter, D.; Schlaermann, P.; Meyer, T.F.; et al. Helicobacter pylorivacA genotype is a predominant determinant of immune response toHelicobacter pyloriCagA. World J. Gastroenterol. 2017, 23, 4712-4723. [CrossRef] [PubMed] 
43. Pormohammad, A.; Ghotaslou, R.; Leylabadlo, H.E.; Nasiri, M.J.; Dabiri, H.; Hashemi, A. Risk of gastric cancer in association with Helicobacter pylori different virulence factors: A systematic review and meta-analysis. Microb. Pathog. 2018, 118, $214-219$. [CrossRef] [PubMed]

44. Román-Román, A.; Martínez-Carrillo, D.N.; Atrisco-Morales, J.; Azúcar-Heziquio, J.C.; Cuevas-Caballero, A.S.; Castañón-Sánchez, C.A.; Reyes-Ríos, R.; Betancourt-Linares, R.; Reyes-Navarrete, S.; Carmen, I.C.-D.; et al. Helicobacter pylori vacA s1m1 genotype but not cagA or babA2 increase the risk of ulcer and gastric cancer in patients from Southern Mexico. Gut Pathog. 2017, 9, 18. [CrossRef] [PubMed]

45. Yamaoka, Y. Mechanisms of disease: Helicobacter pylori virulence factors. Nat. Rev. Gastroenterol. Hepatol. $2010,7,629-641$. [CrossRef]

46. Belda, S.; Saez, J.; Santibáñez, M.; Rodríguez, J.; Sola-Vera, J.; Ruiz-Garcia, M.; Brotons, A.; Lopez-Girona, E.; Perez, E.; Sillero, C.; et al. Relationship between bacterial load, morbidity and cagA gene in patients infected by Helicobacter pylori. Clin. Microbiol. Infect. 2012, 18, E251-E253. [CrossRef]

47. Talarico, S.; Safaeian, M.; Gonzalez, P.; Hildesheim, A.; Herrero, R.; Porras, C.; Cortes, B.; Larson, A.; Fang, F.C.; Salama, N.R. Quantitative Detection and Genotyping ofHelicobacter pylorifrom Stool using Droplet Digital PCR Reveals Variation in Bacterial Loads that Correlates withcagAVirulence Gene Carriage. Helicobacter 2016, 21, 325-333. [CrossRef]

48. Atherton, J.C.; Tham, K.T.; Peek, J.R.M.; Cover, T.; Blaser, M.J. Density of Helicobacter pylori Infection In Vivo as Assessed by Quantitative Culture and Histology. J. Infect. Dis. 1996, 174, 552-556. [CrossRef]

49. Simala-Grant, J.L.; Taylor, D.E. Molecular biology methods for the characterization of Helicobacter pylori infections and their diagnosis. APMIS 2004, 112, 886-897. [CrossRef] 